\title{
ULAMA, STATE, AND POLITICS IN MYANMAR
}

\author{
Naw Lily Kadoe*; Fatimah Husein** \\ *Indonesian Consortium for Religious Studies Yogyakarta, Indonesia; \\ ** Coresponding Author, Sunan Kalijaga State Islamic University \\ Yogyakarta, Indonesia \\ email:fatimahbusein@yahoo.com
}

\section{Abstract}

Issues related to Islam and Myanmar have become world's attention, especially in relation to the Rohingya refugees who fled the country in the past few months. The 2010 government census stated that Muslim constitutes 3.9\% of the total 53 million population, who are mainly Theravada Buddhists; but some Muslim leaders interviewed in September 2014 argued that the followers of Prophet Mubammad constituted 17\%. This paper finds that violent conflicts involving Muslims and Buddhists in Rakhine State were caused by complex issues including the bistorical background of the coming and development of Islam in Myanmar and the authoritarian military regime, which did not open paths for dialogue. It is surprising to witness how the concept of "peace" that is at the heart of the Buddhist teaching seems to be disappeared in the whole issue of the conflicts. This paper, however, will not focus on the conflicts themselves but on the role of ulama during the Myanmar conflict.

Isu terkait Islam dan Myanmar telah menyita perhatian dunia, khususnya setelah adanya para pengungsi Rohingya yang keluar dari negeri ini beberapa bulan yang lalu. Sensus tabun 2010 yang dilakukan pemerintah menunjukean bahwa penhanut Islam berjumlah 3,9\% dari total 53 juta penduduk yang mayoritas penganut Budha Theravada; namun menurut beberapa tokoh Islam yang diwawancarai pada September 2014, penganut Islam mencapai 17\%. Tulisan ini melihat babwa konflik kekerasan antara Muslim dan Budha di Provinsi Rakhine dilatarbelakangi persoalan yang cukup komplek, termasuk latar sejarah masuk dan berkembangnya Islam di Myanmar serta rezim militer yang otoriter yang tidak pernah membuka 
Naw Lily Kadoe \& Fatimah Husein

ruang dialog. Satu halyang cukup mengejutkan adalab konsep "damai" yang menjadi jantung ajaran Budha tampaknya hilang di telan pusaran konflik. Hanya saja, tulisan ini tidak berfokus pada isu konflik itu sendiri, namun lebih menelisik peran ulama dalam konflik Myanmar.]

Keywords: Myanmar, Rohingya, Islam-Budhism conflict

\section{A. Introduction}

Myanmar (The Republic of the Union of Myanmar), formerly known as Burm, ${ }^{1}$ is the second largest country in Southeast Asia, neighbored with Bangladesh and India in the west, China in the northeast, and Laos and Thailand in the east. Its population is about fifty-three millions, ${ }^{2}$ living in the area of 262,118 square miles or 675,581 square kilometers. Myanmar is one of the ethnically diverse countries in Southeast Asia. The government recognizes 135 distinctive ethnic groups which are categorized into eight: majority group Bamar, and minority groups Shan, Kachin, Kayin, Kayah, Chin, Mon, and Rakhine. Theravada Buddhism is the heart of Myanmar's national identity. According to the 1983 population census of Myanmar, Buddhist constitutes 89.4\%, Anamist 1.2\%, Hindu 0.5\%, Muslim 3.9\%, Christian 4.9\% and others $0.1 \% .^{3}$

Since Myanmar has been under authoritarian military rule for half a century, political, economic, culture, social and all areas of people's lives are controlled by the state. For several cases, ethno-religious conflicts in Myanmar could be seen as creation of the government to distract people's attention from its failure causing public dissatisfaction. This paper explores the role of ulama in Myanmar, where the Muslims are minority, their relation to Islamic education, and religious conflicts between Buddhists and Muslims, and to international and local pressures. It will also scrutinize the ulama's response to these pressures, the Rohingya issue in Myanmar, and whether ulama contribute significantly or insignificantly

1 The English name of Burma was changed into Myanmar in 1989 by the military government. Burma and Myanmar will be alternatively used in this paper; Burma for the country's name before 1989 and Myanmar, after that year.

2 According to the 2014 census, the provisional result of total population is $51,419,420$ but it excludes the people in the border areas, when civil wars are breaking out, and some Muslims refugees in Rakhine State. Taw, 2012).

${ }^{3}$ Central Statistical Organization, Statistical Year Book 2010 (Myanmar: Nay Pyi 
to the social and political issues of Myanmar Muslim community. This paper will present a brief history of the coming of Islam in Myanmar, Muslims as minority and the issues they were facing in the country, how they responded to these issues, and the role of ulama in the State and politics of Myanmar.

\section{B. The Coming of Islam in Myanmar}

Although there is no written evidence, it is said that the first Muslim arrived in Burma was Sayed Mohammad al-Hanafia, one of the sons of Caliph Ali in A.D 680. He defeated and married the native queen of the northern Rakhine, and the queen and her followers converted to Islam. ${ }^{4}$ According to Myanmar and non-Myanmar sources, Islam reached the shores of Arkan (now RakhineState) as early as 712 A.D via merchants and in the form of Sufism. ${ }^{5}$ Burmese and non-Burmese sources stated that a few shipwrecked people of Arabs, Moors and Persians had settled in the $8^{\text {th }}$ century in Arakan State, and Arab and Persian Muslim seamen first reached in the coastal regions of lower Burma in the $9^{\text {th }}$ century. Some of them were forced to seek refuge on shore due to shipwrecks and remained to settle there. ${ }^{6}$ The very first Muslim traders to be mentioned in Burmese chronicles were the two sons of an Arab merchant who were saved from the shipwreck vessel on the shores of Martaban in the year 1055. ${ }^{7}$ According to the Burmese chronicles, these Muslims and their descendents as well as the prisoners of wars had served the Burmese kings in military service, governance and education, and the kings settled them on the land in various places. ${ }^{8}$ In the course of time, Muslim population increased, partly as a growing numbers of descendants of mixed marriages and partly as the incoming Muslim traders and adventurers. ${ }^{9}$ These Muslims were married to native women, and their offspring were the nucleus of today's Burmese Muslims.

Chinese Muslims came from Yunan, western China bordering

${ }^{4}$ Ezati Abu al-Fazl, The Spread of Islam: the Contributing Factors, 4th ed. (London: Islamic College for Advanced Studies Press, 2002), pp. 481-2.

${ }^{5}$ Mohammed Mohiyuddin and Mohammed Sulaiman, "Islamic Education in Myanmar: a Case Study", in Dictatorship, Disorder and Decline in Myanmar, ed. by Trevor Wilson (Canberra: ANU E Press, 2008), p. 177.

${ }^{6}$ Moshe Yegar, The Muslims of Burma: A Study of Minority Group (Wiesbaden: Otto Harrassowitz, 1972), p. 172.

7 Ibid.

${ }^{8}$ Ibid., pp. 2-3.

9 Ibid., p. 8. 
Burma. The majority of them reached Burma as traders, muleteers and refugees after the failure of Panthay revolt (1856-1873) against the Chinese emperors. They settled in the Shan State of Burma. They are known as Panthay in Myanmar and Hui in Chinese languages. They assimilated with the local community easily but maintained their Muslim identity. ${ }^{10}$ Nowadays, their communities can be found in many parts of Myanmar.

The British conquest of Burma in the second half of the nineteenth century, however, changed the life of Muslim community due to the extensive flow of immigration from India. Before this massive immigration, Muslim community in Burma was small, accepted, loyal to the kings, inactive and unnoticed. At the beginning of nineteenth century, the Muslim immigrants from India doubled the number of local Muslims and they developed religious activities such as establishing mosques, religious schools and other institutions. This creation of a large new and more advanced minority of foreigners caused tension with local population. ${ }^{11}$ The widespread custom of mixed marriages between the Muslim immigrants from India and the local Burmese Buddhist women also caused an anxiety to many Burmese Buddhists and was also exploited for anti-Muslim propaganda by the nationalist movement. ${ }^{12}$ By the beginning of the twentieth century, Indian immigrants were arriving at the rate of 250,000 per year though not all of them settled but remained only for a few years and returned to India with their savings. Tension between the Burmese and the Indians became apparent only after World War I. In 1930, there was a serious anti-Indian outbreak due to the competition of jobs between Indian and Burmese laborers in Rangoon (Yangon).In 1938, however, the riots were aimed at the Muslim community alone due to a book insulting to Buddhists' feelings written by a Muslim. The riots started in Rangoon, spread out to other cities and Buddhist monks were actively participated in these riots. ${ }^{13}$

The Bengali Muslims live mostly in the northern part of Arakan (Rakhine State), the point of contact with East Bengal. Bengal population converted to Islam in 1203, and the cultural and political Muslim influence was significant in the history of Arakan. ${ }^{14}$ In 1404, Narameikhla, the

\footnotetext{
${ }^{10}$ Ibid., pp. 54-5.

11 Ibid., p. 33.

12 Ibid., p. 38.

${ }^{13}$ For more information, see Yegar, The Muslim of Burma, Chapter 2.

14 D.G.E. Hall, A History of South-East Asia (London: Macmillan, 1958), p. 328.
} 
Arakan King, had to flee from Burmese invading army to take refuge in Ahmad Shah, Bengal Sultan at that time. He regained the Arakan kingdom with the help of Muslim soldiers supplied by Nadir Shah, the successor of Ahmad Shah. Upon his return in 1430, Narameikhla built a new city, Mrohaung (Mrauk-U), and made his Muslim soldiers who came with him from Bengal settled in a village near Mrohaung and built the Sandikhan mosque, which still exists today. ${ }^{15}$ Early in the seventeenth century, the Portuguese reached the shores of Arakan and Bengal. Joint ArakanPortuguese raids on Bengal continued until the end of the eighteenth century. All the artisans among the captives were given to the Arakan kings, and the rest were sold on the market or forced to settle in the villages near Mrohaung. In addition to the Muslim prisoners and slaves brought to Arakan from Bengal and even from North India, many more came to serve the Arakan kings as mercenaries and the king's bodyguards. ${ }^{16}$

In 1600, the Mogul prince Shah Shuja took refuge in Sandathudama, King of Arakan (1652-1687), after the defeat of his struggle for succession between the sons of Mogul Emperor Shah Jahan. Soon after that there was a clash between them and ended up with the execution of Muslim group. Those of Shah Shuja's soldiers who escaped the massacre were admitted to the king's bodyguard as a special archers unit called Kamans (from the Persian: bow, kaman). Later on, most of the Kamans were exiled to Ramree (Yanbye Island). ${ }^{17}$

Since 1879, during the British colonial rule, there were massive waves of immigration from Chittagon (East Bengal), and the northern part of Arakan has been overrun by the Chittagonian immigrants. ${ }^{18}$ They have been moving southwards and gradually displacing and overrunning the Arakanese. In 1941, there were only a few scattered groups of Arakanese villages left in the northern Arakan state. There was a great deal of intermarriages between the races, usually Chittagonian men and Arakanese women. The children of these marriages were brought up as Muslims with Chittagonian outlook. ${ }^{19}$ The relationship between the Chittagonian Muslims and Arakan Buddhists during the Japanese

15 Yegar, The Muslim of Burma, p. 22.

16 Ibid., p. 24.

17 Ibid., pp. 25-9.

18 R.B. Smart, Burma Gazetteer. Akyab District, vol. A (Rangoon: Government Printing, 1917), pp. 89-90.

19 Peter Murray, Foreign Office, S.W.1. F 1323/1015/79 (26 Jan 1949), www. networkmyanmar.org/images/stories/PDF13/peter-murray-26011949-rev.pdf, accessed 1 May 2014. 
occupation was recorded by a British officer Peter Murray as follows:

The two communities lived intermingled under Britishrule for 116 years without much incident, though the latenthostility between them flared up into occasional riots andmurders. At the beginning of 1942, the British administrationcollapsed, and the Japanese with the assistance of theArakanese occupied Akyab early in May. They did not movenorth of Akyab until October 1942; and in the meantime, thearea of mixed population was the scene of repeated large-scalemassacres in which thousands of people perished or diedsubsequently of starvation and exposure. Eventually the twocommunities separated into distinct areas, the Arakanese in thesouth supporting the Japanese and the Chittagongians in thenorth supporting the British. The area was a battleground forthe next two years, and was thoroughly devastated by eitherside. Numbers of Moslems fled northward to their relatives or torefugee camps in Chittagong; but the fact is that at no time did the Japanesesucceed in overrunning the entire area was in great measuredue to the staunch loyalty to the Allies of the Moslems whoremained. ${ }^{20}$

Since then, even until today, the relationship between the Muslims and Buddhists in the northern Arakan state has been hostile and antagonistic, and inter-communal violence has been occasionally broken out in Rakhine State.

\section{Muslims in Today Myanmar}

Although the government claims that Muslims consist of 3.9 percent of the total population, Muslim leaders said that Muslim population in Myanmar is about 8,500,000, 17\% of the total population. ${ }^{21}$ Sunni is the majority, besides about 20,000 Shiite Muslims, smaller Ahmadiyya, ${ }^{22}$ and Ismaili communities. ${ }^{23}$ Islam and its related affairs in Myanmar are controlled, managed and regulated by the Ministry of Religious Affairs of Myanmar. There is no desk for Islam or other religious minorities in the Religious Affairs Ministry. Nor is there budget

20 Ibid.

${ }^{21}$ Interview with the Chairman of the Myanmar Islamic Religious Affairs Council (HQ), by Lily Kadoe (29 Sep 2014).

${ }^{22}$ Interview with Shiite and Ahmadiyya Muslims in Yangon, by Lily Kadoe (2012).

23 "Photo Essay: The Ismaili Jamatkhana in Myanmar, With Notes on the Community's Patriotic Spirit", Simerg Photos (13 Apr 2014), https://simergphotos. com/2014/04/13/photo-essay-the-ismaili-jamatkhana-in-myanmar-with-notes-onthe-communitys-patriotic-spirit/, accessed 15 Apr 2014. 
allocation for them but the government contributes 100,000 Kyats (about $\$ 100)$ for the year of $2014 .^{24}$

The first Muslim religious organization that came into Burma in 1922 was the branch of the Indian Jam 'yyyat al-'Ulama' (the Council of Ulama) affiliated with the Congress Party in India. Its name was "Jam 'yyyat al- 'Ulama' Province of Burma." At the end of World War II, it was reorganized under the new name, "Al-Mashikhat al-Islamiyya." On the eve of Burmese independence, the organization again changed its name to "Jam'iyyat al-Islam Burma."' Although a parallel organization was founded in Upper Burma in 1946, the two organizations united into single body called "Jam 'iyyat al- Ulama' Burma” after the independence in 1948. In 1958, there was a split in the Ja'miyyat which led to the formation of the Burma Muslim Organization. The split was caused by disputes on religious-national subject between Indian Muslims and Burmese Muslims. ${ }^{26}$ Moreover, some other separate Muslim religious organizations were also set up after independence. Despite the splits and antagonisms among the various organizations, Muslims in Burma had to cooperate in a few projects such as celebrations of the Prophet's birthday and other major events of celebrations, the struggle to obtain government permission for the slaughter of cattle for religious purposes, and the care and maintenance of the religious buildings. ${ }^{27}$

The Myanmar government deals withIslamic affairs through five Islamic Associations, namely: The Islamic Religious Affairs Council (HQ), Jamiat 'Ulama-al Islam (HQ), All Myanmar Maulawi Association, Myanmar Muslim Youth's Religious Organization, and Myanmar Muslim National League. ${ }^{28}$ These five associations are collectively known as Myanmar Islamic Religious Organization, which sent formal letters to the authorities and the government whenever Islam and the Muslim communities in Myanmar were assaulted by the Buddhist nationalists. ${ }^{29}$

${ }^{24}$ Interview with the Chairman of the Myanmar Islamic Religious Affairs Council (HQ).

${ }^{25}$ Yegar, The Muslim of Burma, p. 104.

${ }^{26}$ Ibid., pp. 104-5.

${ }^{27}$ Ibid., pp. 108-10.

28 Ibid.

29 "Islamic Associations in Myanmar call for peaceful settlement of Rakhine incident”, English.news.cn (20 Aug 2012), http://news.xinhuanet.com/english/ world/2012-08/20/c_131795787.htm, accessed 21 Aug 2012; Chan Nyein Aye, "Myanmar Islamic Religious Organization sends a formal demand letter to the President for proceedings against the Aung Jeyatu Journal that has committed Religious Offense", Al-Jāmiah, Vol. 53, No. 1, 2015 M/1436 H 
In terms of education, the Islamic education system in Myanmar has been criticized by many Muslims, local and international bodies. They see the curriculum and the prescribed books are outdated and most of them written in Urdu language. Madrasabs (Islamic schools) in Myanmar are called maktabs where the only alternative for educating Muslims is offered since the national school system does not provide any teaching on particular faith or belief. They are predominantly male boarding schools where students study for ten or more years. After completion of their studies, students can go abroad for further study. Many of them go to India, Pakistan and Bangladesh but few students go to Arab countries, especially to Mecca, Egypt, and Turkey. Most of the Myanmar Muslim parents in big cities send their children to the government national schools and the children can study Islamic education after school or weekends at the maktabs. ${ }^{30}$

Religious teachers are not free from criticism. Imams, especially in the Rakhine State, are accused of holding too traditional and conservative in religious teachings. Their curriculum is outdated; some books were written one or two hundred years ago. Many of them, especially Indian and Bengali teachers, cannot speak Burmese, the national language, well. Most of them have their education from Bangladesh, India and Pakistan. Since the madrasabs in Myanmar offer purely religious curriculum, that is, the Quran, Hadith, Arabic, Urdu, and some English, religious teachers fail to understand economic and social affairs of the community. As they also fail to understand the affairs of people of other faiths, so much so that they are not getting along with non-Muslims in the society. In addition, many Muslims complain that there are very few qualified scholars among ulama. The leaders of Islamic Religious Affairs Council are aware of the need of curriculum updates for the madrasabs in Myanmar. ${ }^{31}$

Ishak Mia Sohel, an independent analyst who resides in Dhaka, Bangladesh, also urged for the reformation of madrasab education in Myanmar. He sees the disadvantage of Islamic education in Myanmar as partly because of the government policy towards religious minority and partly because of the ignorance of the teachers and parents to modernize

M-Media English (22 Oct 2014), http://www.m-mediagroup.com/en/archives/8460, accessed 23 Oct 2014.

30 "Islamic Associations in Myanmar"; Aye, "Myanmar Islamic Religious".

31 "Islamic Associations in Myanmar"; Aye, "Myanmar Islamic Religious". 
the curriculum for the children of twenty-first century. ${ }^{32}$

Myanmar Muslim from Upper Burma are considered to be more liberal in Islamic thoughts and more accommodating towards different ethnic groups and other faiths. Madrasabs in this area teach student to be more open-minded than those in other areas and no particular form of dress is considered 'pious'. Madrasabs in Lower Myanmar, however, make it compulsory for their students to dress in Indian style, wearing kurta and fez. All madrasah teachers in Lower Burma wear pious kurta and fer dress. ${ }^{33}$

\section{Recent Buddhist-Muslim Conflicts in Myanmar}

June 2012 witnessed the first and most widespread violence, riot and clashes between Rakhine Buddhists and Muslims, largely said to be Rohingya Muslims, and left 200 dead and thousands displaced. It was the rape and murder of a young Buddhist woman that sparked of that deadly chain of events. Another violence broke out again in October of that year and non-Rohingya Muslims were also targeted by the Buddhist mobs.

In March 2013, an argument in a gold shop in Meiktila in central Myanmar led to violence between Buddhists and Muslims which left more than 40 people dead and the entire neighborhood razed. This was followed by another incident in August 2013 in which rioters burnt Muslim-owned houses and shops in the central of Kanbalu after the police refused to hand over a Muslim man accused of raping a Buddhist woman. In January 2014, the UN said that more than 40 Rohangya men, women and children were killed in Rakhine state in violence that flared after accusations that Rohingyas killed a Rakhine policeman. It did not stop there as in June 2014, two people were killed and in Mandalay, Myanmar's second city, following a rumor that spread on social media that a Buddhist woman had been raped by her Muslim employers. ${ }^{34}$ It was found out that the accusation of that woman was not true and she was paid to do so.

There were also other conflicts between the Buddhist and Muslim communities in some towns all over Myanmar since 2012. Many people

32 Ishak Mia Sohel, "The Urgency of Reforming Madrasa Education in Myanmar", OpenDemocracy (28 Nov 2014), http:/ / www.opendemocracy.net/ishak-miasohel/urgency-of-reforming-madrasa-education-in-myanmar, accessed 29 Nov 2014.

33 Mohiyuddin and Sulaiman, "Islamic Education", p. 183.

34 “Analysis: Violence in Myanmar", GulfNews (13 Jul 2014), http://gulfnews. com/news/europe/analysis-violence-in-myanmar-1.1356311, accessed 7 Aug 2014. 
notice that these conflicts and violence were followed by hate speeches against Islam and Muslims in some Buddhist monks' sermons, social media, pamphlets and stickers distributed by the Association of the Protection of Race and Religion, known as $\mathrm{Ma} \mathrm{Ba}$ Tha in Burmese. Buddhist nationalist groups, counted the 969 Movement an anti-muslim campaign led by Buddhist extremist call for boycotts on Muslim shops and encourages attacks on muslim communities, although the eviction of Muslim from Myanmar. ${ }^{35}$

A recent opinion poll of Myanmar people placed inter-communal conflict as the second-biggest problem facing the country today, behind unemployment. ${ }^{36}$ (The displacement of the rohingya has significantly increased tension between Myanmar and its neighbors. ${ }^{37}$ Unemployment also become part of biggest problem in country of transit. This problem certainly an issues that protracted for a country of transit because of the absence of the destination country willing to accept refugees from rohingya.)

Various sources from incidents of inter-communal conflict since 2012 demonstrate failures by local officials and security forces in responding to threats to property and life equally, and in some cases direct involvement in violence against Muslims. ${ }^{38}$ Even violence in 2012, $44 \%$ of the population of Rakhine State lives below the poverty line, almost 20 percent higher than the average in most parts of Burma. In addition, the condition is aggravated by government policy of increased and repression and denial of humanitarian assistance, is working in terms of achieving their goals. ${ }^{39}$

In response to these conflicts, both local and international organizations have shown their concerns but most of the outrage has come from the Muslim world. Saudi Arabia has accused Myanmar of launching an 'ethnic cleansing campaign' and King Abdullah announced

35 "Global Conflict Tracker Sectarian Violence in Myanmar: Intensification od Sectarian Violence Between Buddhist and Muslim Rohingyas in Myanmar", cfr.org, http://www.cfr.org/global/global-conflict-tracker/p32137\#!/, accessed 22 Oct 2015.

36 Stephen Gray and Josefine Roos, Intercommunal Violence in Myanmar: Risk and Opportunities for International Assistance (Adapt Research and Consulting, 2014), p. 4.

37 "Global Conflict Tracker Sectarian Violence in Myanmar".

38 Ibid.

39 The Humanitarian Crisis of Robingya in Rakbine States: A Briefing by Burmese Rohingya Organisation UK, (London: Burmese Rohingya Organisation UK, 2014), p. 2, http://burmacampaign.org.uk/media/The-Humanitarian-Crisis-Of-Rohingya-InRakhine-State.pdf. 
that he would donate $\$ 50$ million in aids to the Rohingya in Myanmar. Islamic hardliners in Indonesia and Pakistan have threatened attacks against the Myanmar government. Indonesia's former Foreign Minister Marty Natalegawa toured several refugee camps in Rakhine State and has pledged $\$ 1$ million in financial assistance to help build shelters, schools and other public facilities in Rakhine State. He further pushed the government of Myanmar to facilitate a reconciliation program that would bring the Rakhine and Rohingya into peaceful conflict resolution. In addition, he promised that Indonesian government would share its experience in handling communal conflict. He also said that resolving the issue of Rohingyas' citizenship would be an important component of the reconciliation process. ${ }^{40}$

Muslim In Indonesia playing a vital role to show solidarity with the Rohingya, therefore many Indonesians pressed the government to accommodate migrants in Aceh Province. ${ }^{41}$ Tri Nuke Pjiastuti, researcher of LIPI, said that refuges of Rohingya will be longer placed in Indonesia because so far no destination country willing to accept them, as do Australia and compounded by the refusal of Myanmar. ${ }^{42}$

The 57-nation Organization of Islamic Cooperation (OIC) condemned the violence which they branded as 'genocide of Rohingya Muslims' in Myanmar at the summit meeting in Mecca in August 2012 and presented its concern to the UN General Assembly. On the other hand, Myanmar government invited many international and UN teams to probe of the violence to witness the reality in Rakhine State. The OIC was allowed to open an OIC liaison office in the capital of Rakhine State yet the government decided not to do so after many Rakhine and Burmese people objected the plan. Thousands of monks took to the

${ }^{40}$ Ismira Lutfia Tisnadibrata, "Khabar: Burma Welcomes Indonesia’s Engagement: Natalegawa", Khabarsoutheastasia.com (16 Jan 2013), http://khabarsoutheastasia.com/ en_GB/articles/apwi/articles/features/2013/01/16/feature-03, accessed 17 Jan 2013.

${ }^{41}$ Jerome Wirawan, Asia Migrants: what do those in the region think should be done? Indonesia: "We should help, but Rohingya should go home afterwards", See also Mariko Oi, "Asia Migrants: What do Those in the Region Think Should be Done?”, BBC News (24 May 2015), http:/ /www.bbc.com/news/world-asia-32824199, accessed 23 Nov 2015.

${ }^{42}$ Heyder Affan, “Masalah pengungsi Rohingya 'sulit diselesaikan' dalam setahun”, BBC Indonesia (23 Nov 2015), http://www.bbc.com/indonesia/berita_ indonesia/2015/06/150605_indonesia_nasib_rohingya, accessed 23 Nov 2015. 
streets of Yangon and Mandalay against the office's opening. ${ }^{43}$ Although the OIC could not open offices in Myanmar, the government allowed them to visit and investigate the situation of the Rohingya refugees in November 2013. However, the delegation of the OIC had met thousands of protesters against their visit in Rakhine State. Protests against the visit of OIC delegates were also held in Yangon, Meiktila in Manadalay Divisihon and Lashio in northern Shan State where Buddhist-Muslim conflicts were taken place. ${ }^{44}$

Inside Myanmar, Muslims in Yangon refrained from celebrating the Islamic festival of Eid Al-Adha in October 2012, in solidarity with their fellow Muslim Rohingyas who were suffering in Rakhine State. Myo Latt, a senior leader of the Burmese Muslim Association said, "Our brothers and sisters are being murdered and their villages are being burned down in Arakan State. It is for this reason that we will not celebrate Eid." ${ }^{45}$

On the other hand, in December 2012, international Buddhist leaders urged the Myanmar government to show mutual respect and compassion to Muslims in Rakhine State. The statement came after many Myanmar Buddhist monks and abbots led demonstrations and advocated the deportation of Rohingya Muslim community from Myanmar. It stated: "We wish to reaffirm to the world and to support you in practicing the most fundamental Buddhist principles of non-harming, mutual respect and compassion." 46

It is reported that Myanmar also rejected an offer by the Turkish government to rebuild around 5,000 houses for displaced Rohingya Muslims after the protests in several different towns over this issue. A Burmese from the capital city Sittwe said that they have no problem with building homes for those who qualify as citizens under the existing law but

43 "Myanmar: Government rejects OIC office request for troubled Rakhine", IRIN (16 Oct 2012), http:/ / www.irinnews.org/report/96562/myanmar-governmentrejects-oic-office-request-troubled-rakhine, accessed 17 Oct 2012."

${ }^{44}$ Lawi Weng, "OIC Delegation met by angry protesters in Sittwe", Irrawaddy. com (11 Dec 2013), http://www.irrawaddy.com/burma/oic-delegation-met-angryprotesters-sittwe.html, accessed 15 Nov 2013.

${ }^{45}$ Lawi Weng, "Burmese Muslims cancel Eid Festivities", Irrawaddy.com (24 Nov 2012), http://www.irrawaddy.com/conflict/burmese-muslims-cancel-eid-festivities. html, accessed 24 Oct 2012.

46 "International Buddhist leaders urge Burmese to show compassion for Rohingyas", Mizzima News (12 Aug 2012), http://archive-2.mizzima.com/news/ inside-burma/8537-international-buddhist-leaders-urge-burmese-to-show-compassionfor-rohingyas.html, accessed 22 Apr 2016. 
they would not be happy if illegal immigrants from a foreign country are being given homes in their land. ${ }^{47}$ They did believe that there are illegal immigrants from Bangladesh among the Muslim groups. According to the Burmese citizenship law, only the third generation of the immigrants would be granted citizenship status.

Ongoing tension between Rakhine and Rohingya has created difficulties for the aid workers, hindering assistance to the displaced persons at refugee camps in Rakhine State. The staffs of humanitarian organizations have faced accusations from the local Rakhine community that their assistance favoured the Muslim Rohingyas as there were also hundreds of Rakhine among the refugees. Verbal harassment was mostly directed at the local aid workers and their families were also vulnerable. ${ }^{48}$ In February 2014, the government expelled Médecins Sans Frontières (MSF), also known as Doctors without Borders, over perceived- bias towards Rohingyas. A month later, international aid workers had to flee when Rakhine mob targeted their offices after a rumor that an aid worker improperly handled a Buddhist flag. It is very clear that antiforeign sentiment is among the Burmese Buddhist nationals and they see Western aid workers as "light-skinned Kala" and Rohingya as "darkskinned Kala." ${ }^{49}$

The Human Rights Watch (HRW) report released on April 22, 2013 has received the criticism from many Myanmar nationals too. The '88 Generation Students Group and the President's Spokesman responded the report as unacceptable one-sided report, and lack of loses and sufferings of the Rakhine nationals and their human rights violations. They warned the HRW that their report could exacerbated the ethnic problem and affect Myanmar's democratic reform. ${ }^{50}$ The former UN special rapporteur for human rights in Myanmar, Thomas

${ }^{47}$ Hanna Hindstrom and Aye Nai, "Local hostility threatens Arakan reconstruction pledge”, DVB Multimedia Group (11 Apr 2013), http://www.dvb.no/ news/local-hostility-threatens-arakan-reconstruction-pledge/27574, accessed 21 Apr 2013.

48 "Sectarian tension in Myanmar threatens aid workers", IRIN (16 Apr 2013), http://www.irinnews.org/report/97852/sectarian-tension-myanmar-threatens-aidworkers, accessed 16 Apr 2013.

49 "Kala" is the derogatory Burmese term for foreigner.

50 "HRW's report on Rakhine conflict can affect democratic reform: '88 group says", Eleven Myanmar, http://elevenmyanmar.com/politics/3281-hrw-s-report-onrakhine-conflict-can-affect-democratic-reform-88-group-says\#.UX6j_A5d3Gc.twitter, accessed 29 Apr 2013. 
Ojea Quintana and the UN General Secretary Ban Ki-moon were not free from criticism by the Burmese nationals. Quintana was accused for his one-sided comments on Rohingya issue and Ban was protested in Yangon for using the name Rohingya in his speech in November 2014. Rakhine community from Maungdaw protested after the United Nations General Assembly's Human Rights Committee adopted the resolution on November 21 urging Myanmar to grant full citizenship to the Rohingya. However, Burmese representative opposed the use of term "Rohingya" in the Resolution and warned that the use of this word by the United Nations will upset Burmese people and make the government's work more difficult in dealing with this issue. ${ }^{51}$

Furthermore, many Muslims around the world protest against the Burmese government for its ill-treatment to Rohingyas in Rakhine State of Myanmar. The Burmese Rohingya Organization UK (BROUK) appealed to UN General Assembly to push pressure on Burmese President Thein Sein for his proposal that third countries accept Rohingya refugees. ${ }^{52}$ Accordingly, UN organizations and humanitarian groups called for the citizenship of Rohingya people who are not recognized as citizens of Myanmar.

To make the matter worse, a Bangladeshi journalist Zeeshan Khan wrote an op-ed published in a Bangladeshi newspaper suggesting that Rohingya-majority parts of Rakhine State should hold a referendum on whether to secede from Myanmar in order to join Bangladesh's Chittagong Division or to form independent country between Bangladesh and Myanmar. The Myanmar government summoned the Bangladeshi Ambassador to hand over a memo expressing Naypyidaw's displeasure over the opinion piece, which appeared in the Dhaka Tribune on March $20,2014 . .^{53}$

51 "Protest against UN Secretary-General Ban Ki-moon", The Economic Times (29 Nov 2014), http://economictimes.indiatimes.com/slideshows/dayin-pics/november-29-2014/protest-against-un-secretary-general-ban-ki-moon/ slideshow/45318109.cms, accessed 29 Nov 2014; "Rakhine protests after UN passes resolution on Burma", Kaladan Press Network (23 Nov 2014), http:/ /www.kaladanpress. org/index.php/news/375-news2014/november-2014/4702-rakhine-protestsafter-un\%20passes-resolution-on-burma.html, accessed 23 Nov 2014.

52 "Rohingya NGO Calls on UN to Push Thein Sein", Colin Hinshel Wood (27 Sep 2012), http://www.irrawaddy.com/burma/rohingya-ngo-calls-on-un-to-pushthein-sein.html, accessed 27 Jul 2012.

53 Nyein Nyein, "Govt Complains to Bangladesh Over Rohingya Op-ed", irrawaddy.com (25 Mar 2014), http://www.irrawaddy.com/burma/govt-complains- 


\section{Ulama and Burmese Muslims' Responses}

Whenever international pressures put on the Burmese government on Muslim issues in Myanmar, the Burmese Muslims living inside Myanmar feel uneasy with the greater pressure from nationalist Buddhists. ${ }^{54}$ For instance, many Burmese people misinterpreted the symbol '786' as Muslims' conspiracy to take over Myanmar in $21^{\text {st }}$ century because they see '786' to represent ' 21 ' $(7+8+6=21)$. Their suspicions heightened when they see Muslims only buy food from the shops with the number '786.' Muslim leaders had to clarify that the number ' 786 ' is not representing the Islamization of Myanmar in the $21^{\text {st }}$ century. The Arabic letters of the opening phrase of the Qur'an sum to the numerical value of '786.' Not all Muslims places emphasize on this numerological analysis; however, some (mostly Indian Muslims in Pakistan, India, Myanmar and Bangladesh) use the symbol od '786' as a substitute for Bismillabirrohmanirrohim ("In the name of Allah" or "In the name of God").Moreover, they clarified that Muslims have to make sure foods are halal as they have to follow the strict dietary laws according to their tradition. They also explained the concepts of jihad and missionaries in Islam. In response to the suspicion surrounding mosques, a Muslim leader claimed that the mosque is open to the follower of any religion who wants to inspect on it. ${ }^{55}$ Nonetheless, $\mathrm{U}$ Wirathu from the Masoeyein Monastery states that the Myanmar Islamic Religious Organization needs to announce officially that Islam has no intention of dominating Myanmar in the 21 st century and that those who are reported to be pursuing this objective would be convicted. ${ }^{56}$

On September 30, 2014, Ayman al-Zawahiri, the head of alQaeda, released a video in which he expressed his scheme to form an Islamic Caliphate and he anticipated that his organization, called the Jamä'at Qä'idat al-Jihäd fì Shibh al-Qärra al-Hindìya (the "Organization of the Base of Jihad in the Indian Sub-Continent" or simply Al Qaeda in the Indian Subcontinent/AQIS), would be welcomed by the Muslims in Myanmar, Bangladesh, Assam, Gujarat, Ahmadabad, and Kashmir as he asserted that AQIS would liberate Muslims of South Asia from

bangladesh-rohingya-op-ed.html, accessed 25 Mar 2014.

${ }^{54}$ Interview with Muslim Leaders in Yangon by Lily Kadoe (2014).

55 “Islamic Leaders Officially Explain Meaning of '786”', Democracy for Burma (15 Jun 2013), https://democracyforburma.wordpress.com/2013/06/15/islamic-leadersofficially-explain-meaning-of-786/, accessed 15 Jun 2013.

56 Ibid. 
oppression and injustice. ${ }^{57}$ However, the Burmese Muslim Association (BMA) strenuously condemned that statement saying, "The marginalised minority Muslims in Burma will never accept any help from a terrorist organisation, which is in principle a disgrace and morally repugnant." ${ }^{, 58}$ The BMA also stated that "The Burmese Muslims will not tolerate any threat to their motherland." ${ }^{59}$ Muslim leaders do not think there will be any conflict because of the threat of Al-Qaeda as Burmese Muslims have never retaliated to the Burmese Buddhists by taking arm although they have been ill-treated. They reject terrorism and teach their Muslim youth not to contact any terrorist organization and to live in harmony and peacefully with their Buddhist neighbors. This message is given whenever they carry out youth forums, workshops, seminars and in their sermons at mosques. They do not believe violence is the solution for the ethnic and religious conflicts as Islam is a peaceful religion like other religions. They warn all people in Myanmar to be aware of the plans of those evil people $^{60}$ who ignite the conflictsbetween different religious adherents for their interest. ${ }^{61}$

How do the ulama respond to this situation? When some religious conflicts broke out in many parts of Myanmar, ulama were among the targets of the nationalist Buddhist monks and the mob of the attackers. Mosques, madrasahs, Muslim houses and shops were destroyed, and some teachers and students of madrasabs were killed or injured. In this case, Ulama cannot protect their communities since they are among the victims. Together with other Muslim leaders, however, ulama in Myanmar sent an appeal letter to the government to stop these violent attacks to the Muslim minority groups. ${ }^{62}$

${ }^{57}$ C. Christine Fair, “The Foreign Policy Essay: Al Qaeda's Re-launch in South Asia”, Lawfare (21 Sep 2014), https://www.lawfareblog.com/foreign-policy-essay-alqaedas-re-launch-south-asia, accessed 21 Sep 2014.

${ }^{58}$ Colin Hinshelwood, "Burmese Muslims reject 'morally repugnant' Al-Qaeda", DVB Multimedia Group (6 Sep 2014), http://www.dvb.no/news/burmese-muslimsreject-morally-repugnant-al-qaeda-burma-myanmar/43908, accessed 9 Jun 2014.

59 Ibid.

${ }^{60}$ Many people in Myanmar believe that there is a group or groups who do not want democratic reform of the country. Muslim leaders also believe that conflicts were created by these people.

${ }^{61}$ Al-Hajj U. Nyunt Maung Shein, interview by Lily Kadoe (29 Sep 2014).

${ }^{62}$ Interview with Muslim religious leaders in Yangon by Lily Kadoe in 2014; see also "Muslim Leaders Urge Myanmar to Restore Order", GlobalPost (28 Mar 2013), http://www.globalpost.com/dispatch/news/afp/130328/muslim-leaders-urgemyanmar-to-restore-order, accessed 3 Mar 2013. 
The tasks of ulama in Myanmar today are mainly religious and Islamic education without involvement in politics. The major role of ulama in Myanmar is in determinating the new moon in each month, the declaration of the days of Eid (Eid al-Fitr and Eid al-Adha) and the month of Ramadan, giving Islamic education to the young and adult, producing recommendation letters to those who are going to other countries for religious studies, producing halal certificate for the food products, facilitating for going hajj (pilgrimage), maintaining the principles of Islam, and pronouncing fatwas (religious edicts). ${ }^{63}$

On the other hand, the nationalist Buddhist monk U Wirathu accused the ulama of teaching or indoctrinating their students to hate Burmese Buddhists so that the students perceive the Buddhist monks and Buddhists in general as their enemies. ${ }^{64}$ In reality, as argued by Muslim leaders, they and the elders tried to calm their communities and helped the victims with humanitarian aids in refugee camps. Muslims leaders are so sad and feeling discriminated that their appeal to the government was disregarded. ${ }^{65}$

In order to promote harmonious inter-communal relations, Muslim organizations in Myanmar offered Buddhist monks to discuss tolerance among religious communities. One month after the clashes between Buddhist and Muslim communities in Mandalay, on July 28, 2014 during the Islamic festival of Eid al-Fitr the Muslim Social Welfare Group of Mandalay has offered meals and robes to about 50 Buddhist monks at Ma Soe Yein Monastery. About 55 monks in Mandalay, and leaders from Christian and Hindu communities attended that event. ${ }^{66}$

One year before this event, on July 3, 2013 the Interfaith Peace and Unity Group has organized and brought Buddhist monks and Muslim leaders together at a mosque in Yangon. They discussed how to alleviate widespread religious tensions in Myanmar. They planned to hold monthly meeting at different places in Yangon, including a Christian church. Interfaith groups believe that if they can stop the spreading hate in their

${ }^{63}$ Interview with religious leaders in Yangon by Lily Kadoe in 2014.

64 "Nationalist Monk U Wirathu Denies Role in Anti-Muslim Unrest", Irrawaddy. com (29 Mar 2013), http:/ / www.irrawaddy.com/interview/nationalist-monk-u-wirathudenies-role-in-anti-muslim-unrest.html, accessed 29 Mar 2013.

${ }^{65}$ Interviews with Muslim religious leaders in Yangon by Lily Kadoe, in 2014.

${ }^{66}$ San Yamin Aung, "Muslim Organization Makes Offerings to Mandalay Buddhist Monks", Irrawaddy.com (8 Apr 2014), http://www.irrawaddy.com/burma/ muslim-organization-makes-offerings-mandalay-buddhist-monks.html, accessed 8 Apr 2014. 
communities, they can successfully have peace. ${ }^{67}$

\section{Ulama and Robingya Issues}

The term "Rohingya" is a very sensitive and problematic name of the Muslim minority group in Rakhine State, western part of Myanmar. Although these Muslims in Rakhine State named themselves Rohingya, other people call them Bengali or Kalar (Kula). ${ }^{68}$ The Burmese government and many Rakhines rejected the use of the ethnic term "Rohingya" for the Muslims in Rakhine State (Arakan State). In legal terms, the Rohingya does not have Burmese nationality or ethnic nationality status. The government and many Burmese people do not accept the existence of an ethnic group known as the Rohingya. ${ }^{69}$ The Deputy Minister of Immigration and Population Ministry of Myanmar asserts that there has never been a Rohingya race among the country's ethnic groups in Rakhine State according to the censuses conducted in 1973 and 1983, and that term was not mention either in the British gazettes. According to the censuses, non-ethnic citizens in Myanmar included Chinese, Indian, Pakistani, Bengali and Nepalese, he said. ${ }^{70}$ There is no question for the fact that Muslims have inhabited parts of Rakhine for generations but many Rakine and Burmese people claim that there have been illegal migrants from the East Pakistan (Bangladesh) since 1948. Khin Maung Saw argues that the term "Rohingya" denotes the native Rakhine ethnic in Bengali language and it was 'hijacked' or 'kidnapped' by the Bengali Muslims who want to claim themselves as pribumi (people of the soil). ${ }^{71}$

The name "Rohingya" becomes more popular in international media when the bloody conflicts and communal violence between Buddhist Rakhines and Muslim Rohingyas in Rakhine State broke out

${ }^{67}$ Nyein Pyae Sone, "At Rangoon Mosque, Buddhist Monks Accept Alms and Discuss Tolerance”, Irrawaddy.com (4 Jul 2013), http:/ /www.irrawaddy.com/conflict/ at-rangoon-mosque-buddhist-monks-accept-alms-and-discuss-tolerance.html, accessed 4 Jul 2013.

${ }^{68}$ Kalar or Kula is a bigotry term for foreigners especially dark-skinned South Asians. 26 Feb 1992.

${ }^{69}$ Release of the Ministry of Foreign Affairs of the Union of Myanmar on

70 "The New Light of Myanmar", Burmese News Paper (21 Feb 2013), http:// www.burmalibrary.org/docsMA2013/NLM2013-02-21.pdf, accessed 21 Feb 2013.

${ }^{71}$ Khin Maung Saw, "Islamization of Burma through Chittagonian Bengalis as 'Rogingya Refugees"”, burmalibrary.org (http:/ / www.burmalibrary.org/docs21/KhinMaung-Saw-NM- - -Islamanisation_of_Burma_through_Chittagonian_Bengalis-en. pdf 2011), 10/10/2012. 
in June and October 2012. Religious tension was flared in Rakhine State after three Muslim boys were accused of the gang rape and murder of an ethnic Rakhine girl in Ramree, Rakhine State on May 28, 2012. It culminated in a bloody massacre on June 3, 2012 when an angry mob who mistakenly believed those culprits were on board set upon a bus filled with Muslim pilgrims and beat ten of them to death before setting the vehicle ablaze. ${ }^{72}$ The conflict was escalated as rumors and provocation of some anti-Buddhist and anti-Muslim discourses and photos, even fake photos in media and pamphlets. The chauvinist Buddhist monks and Rakhines targeted not only Rohingyas but also all Muslims in Rakhine State. Hundreds of people died and thousands displaced mostly from Rohingya communities. Many Rohingyas fled to Bangladesh but Bangladesh closed its border to the refugees as it has already hosted hundreds of thousands of Rohingya refugees in the country. The government even told the international aid agencies not to help Rohingya refugees to discourage illegal migration from Myanmar. ${ }^{73}$ On the other hand, the UN organizations and NGOs, Islamic countries and many other countries are helping to resettle both Rakhine and Rohingya refugees in Rakhine State. The All Myanmar Islamic Religious Organization has also called for peaceful settlement of disputes in the framework of law with regard to incident which occurred in the country's western Rakhine statein August 2012.

President U Thein Sein told the United Nations High Commissioner for Refugees (UNHCR) in July 2012 that the government will not recognized the Rohingya as an ethnic of Myanmar. He sees that the Rohingya posed a threat to national security. The president then asserted that in accordance with the Burmese Citizenship Law, only a third generation of immigrants who came to Burma before 1948 are recognized as a citizen. As a last resort, the government is prepared to hand over the Rohingyas to the UNHCR and would set up refugee camps for the group before they were eventually settle in any third country that are willing to take them. ${ }^{74}$ Later on, however, he has changed his tone and said that Myanmar would try to improve the education of Rohingya to

72 Kyaymon News Paper, June 5, 2012.

73 "Bangladesh: Refugee Aid Discouraged", The New York Times (2 Aug 2012), p. A7.

74 “Gov't will not recognise Rohingya: Thein Sein”, DV B Multimedia Group (12 Jul 2012), http://www.dvb.no/news/gov\%ee2\%80\%99t-will-not-recognise-rohingyathein-sein/22875, accessed 13 Nov 2015. 
ease tensions. ${ }^{75}$ When brutal violent attacks broke out in other towns of Rakhine State in October, President U Thein Sein urged people to change their attitudes towards the Rohingya and said that the government should promote more education and job opportunities in the Rakhine State along the border with Bangladesh. ${ }^{76}$ Nonetheless, thousands of monks marched in Yangon and Mandalay with the people to express the solidarity with the President's earlier concerns. They called for deportation of the Rohingyas to foreign countries. ${ }^{77}$ Democracy icon Daw Aung San Suu Kyi has been criticized for her silence on ethnic violence in Kachin and Rakhine states. Mark Farmaner from Burma Campaign UK said that it was unfortunate that Daw Aung San Suu Kyi and her party had still failed to address more strongly on Rohingya issue. ${ }^{78}$

The government appointed a commission of 27 members which includes religious leaders, artists and former dissidents in August 2012 to probe the real cause of sectarian clashes in Rakhine State but the commission's report was not satisfactory for the Rohingyas. ${ }^{79}$ There were over 500,000 Rohingyas in mainland Myanmar while about 800,000 living in Rakhine State. Since 1990, Rohingyas from mainland cannot go to their relatives in Rakhine State. Rohingya communities in Butheetaung and Maungtaw townships in northern Rakhine State have to live in a situation like "open-air prison." Many young people risk their lives to run from Rakhine to Bangladesh, Thailand, and Malaysia by boats. Hundreds of them died at sea from sinking ship or of starvation and dehydration. Rohingyas feel that they have heavy discrimination from the Rakhine and the Burmese government. Rohingyas in the cities also are under pressure and they cannot raise a voice for their people. Their appeal letters were neglected by the authorities and they did not have opportunity to

75 Aung Zaw, "Rohingya Attacks Stem from Myanmar's Troubled History", The National (23 Aug 2012), http:/ / www.thenational.ae/thenationalconversation/comment/ rohingya-attacks-stem-from-myanmars-troubled-history, accessed 13 Nov 2015.

76 "Myanmar President urges Change of Attitude Toward Muslim Minority", The Nation (22 Nov 2012), http://www.nationmultimedia.com/breakingnews/Myanmarpresident-urges-change-of-attitude-toward--30192795.html, accessed 14 Nov 2015.

77 Francis Khoo Thwe, "Myanmar Buddhist monks back President Thein Sein's move to expel Rohingyas", AsiaNews.it (4 Sep 2012), http://www.asianews.it/ news-en/Buddhist-monks-back-President-Thein-Sein $\%$ E2\%80\%99s-move-to-expelRohingyas-25723.html, accessed 19 Nov 2015.

${ }^{78}$ Hanna Hindstrom, "MP hits back at official denial of Rohingya", DVB Multimedia Group (22 Feb 2013), http://www.dvb.no/news/mp-hits-back-at-officialdenial-of-rohingya/26571, accessed 20 Nov 2015.

79 Interview with Rohingya leader in Yangon by Lily Kadoe (9 Apr 2014). 
express their grievances in public. Other Muslim organizations cannot help them too as they also are having discrimination and oppression from the Burmese nationalist Buddhists. Muslims in mainland Myanmar are also targets of violent attacks from these groups and Muslims accuse the government as backing them up. ${ }^{80}$

Rohingya Ulama Council (RUC) was formed in 2000 in Malaysia, as an active political and social organization of Rohingya people, working for benefit of whole Rohingya People in Arkan, Pakistan and Bangladesh. RUC formed for struggle of peace in Arakan for Rohingya People, and to raise voice on international media to stop genocide of Rohingya Muslim in Arakan. ${ }^{81}$ Unfortunately, this organization resides in Malaysia, not in Myanmar. Even inside Myanmar, Burmese Muslim religious leaders cannot go to Rohingya communities in Rakhine State. They can just ask help from their friends in government organizations to send humanitarian aids to the refugees there. Rohingya businessmen from Yangon and central Myanmar collect things and send them to Rohingya refugees with the permission of Rakhine government yet not all these things reach to the refugee camps. ${ }^{82}$

According to a Rohingya political leader, Rohingya religious leaders are conventional. Many of them embrace an extreme theology as they receive their education from conservative schools in India, Pakistan and Bangladesh. Girls are not encouraged to study for higher education as their parents ask them to get married at the average of fourteen. The religious leaders oppose family planning which is against Islam so that their birthrate is higher than Rakhine people and Rohingya population is one-third of total population in Rakhine State. The Rohingya and the Rakhine population became half by half in Sittwe, the capital city of Rakhine State before the communal violence broke out in 2012. The rapid growth of Rohingya population is one of the causes of conflict in that area. Rohingya religious leaders cannot lead social and economic affairs of their own communities nor integrate other communities. Rohingya political leaders criticize them for their outdated ideas and lack of modern education. Language is another setback for them. They teach their students in Urdu and explain in Rohingya language, and do not think about learning Burmese language or Rakhine language which

\footnotetext{
${ }^{80}$ Ibid.

${ }^{81}$ http://rohingyaulamacouncil.webs.com/

82 Ibid.
} 
is a requirement to get Myanmar citizenship. ${ }^{83} \mathrm{U}$ Aye Lwin, a prominent Muslim leader at the Islamic Centre of Myanmar in Yangon asserts that Rohingya Muslims are the most unsecured human beings in Myanmar and treated as slaves, if not sub-human, by the ultranationalist Rakhine conniving with local authorities. He also accuses some Rohingya Muslim religious leaders and elders for misguiding and indoctrinating poor and uneducated Rohingyas to stay aloof from the others who are not only non-Muslims but also non-Rohingya Burmese Muslims of different origins. ${ }^{84}$

ulama and Muslims in Myanmar do not build a close relationship with the state. Their voices are not heard or ignored by the government. Only when the government has issues on Islamic affairs or Muslim affairs, the leaders of the five Islamic groups are called for a meeting to discuss about these issues. In these meetings, they can take advantage to present their concerns and talk to the government officials (ministers and directors of Religious Affairs) directly.Usually these officials cannot give any decision but to report the information to "above".

Language and culture became barrier among Muslim groups of Myanmar such as Muslims of Burmese, Indian and Bengali origins. It may also be a cause of disunity among different Muslim ethnic groups. ulama in Myanmar are dominated by the Muslims of South Asian origin, and the way they wear their dress and beard make others see them as foreigners. The government officials are more incline to deal with the Burmese Muslims who are the Muslims of Burmese origin and have no different appearance and dress with other Burmese Buddhists.

\section{E. Concluding Remarks}

In many Muslim dominant countries, ulama played an important role not only in the religious affairs, but also in social, economic and political spheres of Muslim societies. As religious minority in Myanmar, however, ulama in the country failed to give a significant contribution to the Muslim communities. As long as the military controls the state power, both minority's and majority's rights of the citizens will be violated. Whenever they want to extend their power, minority Muslim communities will be used as an easy prey for the scheme of the military regime and ultranationalist Buddhists.

83 Ibid.

84 Al Haj U. Aye Lwin, personal communication (2 Jan 2013). 
Since 2012, when series of Buddhist-Muslim conflicts and communal violence have been broken out in many parts of Myanmar, ulama were among the victims of ethno-religious conflicts and violence. Let alone preventing and saving the Muslim communities, ulama themselves became targets of the violence in many incidents. The cries of the Muslims, the appeal letters of the Myanmar's Islamic Affairs Council, and the petition of the Muslim political parties went to the deaf ear of the government. Hate speeches of the Buddhist nationalists were rampant in media, and pamphlets were distributed to those who showed hostility towards Muslims. The State did not take action to prevent conflicts from escalating and failed to protect Muslims from violent acts of the mobs. International pressure on the Burmese government, however, had a negative impact on the Muslim societies living in Myanmar. Counterviolent actions towards Buddhist Myanmar in Muslim majority countries failed to help the Muslim minority in Myanmar. The government did not seriously care the international pressures, rather heeding the local pressure of the majority Burmese nationalist Buddhists. There will be no religious freedom in Myanmar as long as the military is holding power, and only the Muslims in Myanmar have to strive for their survival and build trust among their own Muslim groups and other religious groups by accommodating themselves in Burmese Buddhist land through intrafaith and interfaith dialogues. 


\section{BIBLIOGRAPHY}

Affan, Heyder, 'Masalah Pengungsi Rohingya 'Sulit Diselesaikan' dalam Setahun", BBC Indonesia, 23 Nov 2015, http://www.bbc.com/ indonesia/berita_indonesia/2015/06/150605_indonesia_nasib_ rohingya, accessed 23 Nov 2015.

"Analysis: Violence in Myanmar", GulfNews, 13 Jul 2014, http:/ gulfnews. $\mathrm{com} /$ news/europe/analysis-violence-in-myanmar-1.1356311, accessed 7 Aug 2014.

Aung, San Yamin, "Muslim Organization Makes Offerings to Mandalay Buddhist Monks", irrawaddy.com/, 8 Apr 2014, http://www. irrawaddy.com/burma/muslim-organization-makes-offeringsmandalay-buddhist-monks.html, accessed 8 Apr 2014.

Aye, Chan Nyein, "Myanmar Islamic Religious Organization Sends a Formal Demand Letter to the President for Proceedings Against the Aung Jeyatu Journal that has Committed Religious Offense", M-Media English, 22 Oct 2014, http://www.m-mediagroup.com/ en/archives/8460, accessed 23 Oct 2014.

"Bangladesh: Refugee Aid Discouraged”, The New York Times, 2 Aug 2012.

Fair, C. Christine, “The Foreign Policy Essay: Al Qaeda's Re-launch in South Asia”, Lawfare, 21 Sep 2014, https://www.lawfareblog.com/ foreign-policy-essay-al-qaedas-re-launch-south-asia, accessed 21 Sep 2014.

Al-Fazl, Ezati Abu, The Spread of Islam, the Contributing Factors, 4th ed., London: Islamic College for Advanced Studies Press, 2002.

"Global Conflict Tracker Sectarian Violence in Myanmar: Intensification on Sectarian Violence Between Buddhist and Muslim Rohingyas in Myanmar", cfr.org, http://www.cfr.org/global/global-conflicttracker/p32137\#!/, accessed 22 Oct 2015.

“Gov't will not Recognise Rohingya: Thein Sein", DV B Multimedia Group, 12 Jul 2012, http:/ / www.dvb.no/news/gov\%e2\%80\%99t-will-notrecognise-rohingya-thein-sein/22875, accessed 13 Nov 2015.

Gray, Stephen and Josefine Roos, Intercommunal Violence in Myanmar: Risk and Opportunities for International Assistance, Adapt Research and Consulting, 2014.

Hall, D.G.E., A History of South-East Asia, London: Macmillan, 1958. 
Hindstrom, Hanna, "MP hits back at official denial of Rohingya", DVB Multimedia Group, 22 Feb 2013, http:/ /www.dvb.no/news/mp-hitsback-at-official-denial-of-rohingya/26571, accessed 20 Nov 2015.

Hindstrom, Hanna and Aye Nai, "Local Hostility Threatens Arakan Reconstruction Pledge", DVB Multimedia Group, 11 Apr 2013, http:/ /www.dvb.no/news/local-hostility-threatens-arakanreconstruction-pledge/27574, accessed 21 Apr 2013.

Hinshelwood, Colin, "Burmese Muslims Reject 'Morally Repugnant' AlQaeda”, DV B Multimedia Group, 6 Sep 2014, http:/ /www.dvb.no/ news/burmese-muslims-reject-morally-repugnant-al-qaeda-burmamyanmar/43908, accessed 9 Jun 2014.

“HRW's Report on Rakhine Conflict Can Affect Democratic Reform: '88 group says", Eleven Myanmar, http://elevenmyanmar.com/ politics /3281-hrw-s-report-on-rakhine-conflict-can-affectdemocratic-reform-88-group-says\#.UX6j_A5d3Gc.twitter, accessed 29 Apr 2013.

"International Buddhist Leaders Urge Burmese to Show Compassion for Rohingyas", Mizqima News, 12 Aug 2012, http://archive-2. mizzima.com/news/inside-burma/8537-international-buddhistleaders-urge-burmese-to-show-compassion-for-rohingyas.html, accessed 22 Apr 2016.

"Islamic Associations in Myanmar Call for Peaceful Settlement of Rakhine Incident", English.news.cn, 20 Aug 2012, http://news. xinhuanet.com/english/world/2012-08/20/c_131795787.htm, accessed 21 Aug 2012.

"Islamic Leaders Officially Explain Meaning of '786", Democracy for Burma, 15 Jun 2013, https://democracyforburma.wordpress. com/2013/06/15/islamic-leaders-officially-explain-meaningof-786/, accessed 15 Jun 2013.

Mohiyuddin, Mohammed and Mohammed Sulaiman, "Islamic Education in Myanmar: a Case Study", in Dictatorship, Disorder and Decline in Myanmar, ed. by Trevor Wilson, Canberra: ANU E Press, 2008.

"Muslim Leaders Urge Myanmar to Restore Order", GlobalPost, 28 Mar 2013, http://www.globalpost.com/dispatch/news/afp/130328/ muslim-leaders-urge-myanmar-to-restore-order, accessed 3 Mar 2013.

"Myanmar: Government Rejects OIC Office Request for Troubled Al-jāmíah, Vol. 53, No. 1, 2015 M/1436 H 
Naw Lily Kadoe \& Fatimah Husein

Rakhine", IRIN, 16 Oct 2012, http://www.irinnews.org/ report/96562/myanmar-government-rejects-oic-office-requesttroubled-rakhine, accessed 17 Oct 2012.

"Myanmar President urges Change of Attitude Toward Muslim Minority", The Nation, 22 Nov 2012, http:/ /www.nationmultimedia. com/breakingnews/Myanmar-president-urges-change-of-attitudetoward--30192795.html, accessed 14 Nov 2015.

"Nationalist Monk U Wirathu Denies Role in Anti-Muslim Unrest", Irrawaddy.com, 29 Mar 2013, http:/ / www.irrawaddy.com/interview/ nationalist-monk-u-wirathu-denies-role-in-anti-muslim-unrest.html, accessed 29 Mar 2013.

Nyein, Nyein, "Govt Complains to Bangladesh Over Rohingya Op-ed", irrawaddy.com, 25 Mar 2014, http://www.irrawaddy.com/burma/ govt-complains-bangladesh-rohingya-op-ed.html, accessed $25 \mathrm{Mar}$ 2014.

Oi, Mariko, "Asia Migrants: What do Those in the Region Think Should be Done?”, BBC News, 24 May 2015, http:/ /www.bbc.com/news/ world-asia-32824199, accessed 23 Nov 2015.

Organization, Central Statistical, Statistical Year Book 2010, Myanmar: Nay Pyi Taw, 2012.

"Photo Essay: The Ismaili Jamatkhana in Myanmar, with Notes on the Community's Patriotic Spirit", Simerg Photos, 13 Apr 2014, https://simergphotos.com/2014/04/13/photo-essay-the-ismailijamatkhana-in-myanmar-with-notes-on-the-communitys-patrioticspirit/, accessed 15 Apr 2014.

"Protest against UN Secretary-General Ban Ki-moon", The Economic Times, 29 Nov 2014, http://economictimes.indiatimes.com/ slideshows/day-in-pics/november-29-2014/protest-against-unsecretary-general-ban-ki-moon/slideshow/45318109.cms, accessed 29 Nov 2014.

"Rakhine Protests after UN Passes Resolution on Burma", Kaladan Press Network, 23 Nov 2014, http://www.kaladanpress.org/index.php/ news/375-news2014/november-2014/4702-rakhine-protests-afterun $\% 20$ passes-resolution-on-burma.html, accessed 23 Nov 2014.

"Rohingya NGO Calls on UN to Push Thein Sein", Colin Hinshel Wood, 27 Sep 2012, http://www.irrawaddy.com/burma/rohingya-ngocalls-on-un-to-push-thein-sein.html, accessed 27 Jul 2012. 
Saw, Khin Maung, "Islamization of Burma through Chittagonian Bengalis as 'Rogingya Refugees"', burmalibrary.org, http:/ /www.burmalibrary. org/docs21/Khin-Maung-Saw-NM- - Islamanisation_of_Burma_ through_Chittagonian_Bengalis-en.pdf 2011, 10/10/2012.

"Sectarian Tension in Myanmar Threatens Aid Workers", IRIN, 16 Apr 2013, http://www.irinnews.org/report/97852/sectarian-tensionmyanmar-threatens-aid-workers, accessed 16 Apr 2013.

Sohel, Ishak Mia, "The Urgency of Reforming Madrasa Education in Myanmar", OpenDemocracy, 28 Nov 2014, http://www. opendemocracy.net/ishak-mia-sohel/urgency-of-reformingmadrasa-education-in-myanmar, accessed 29 Nov 2014.

Sone, Nyein Pyae, "At Rangoon Mosque, Buddhist Monks Accept Alms and Discuss Tolerance", The Irrawaddy, 4 Jul 2013, http://www. irrawaddy.com/conflict/at-rangoon-mosque-buddhist-monksaccept-alms-and-discuss-tolerance.html, accessed 4 Jul 2013.

Smart, R.B., Gazetteer, Burma: Akyab District, vol. A, Rangoon: Government Printing, 1917.

The Humanitarian Crisis of Rohingya in Rakbine States on December 2014, Manor Park: BROK, Burmese Rohingya Organisation UK, 2014, http://burmacampaign.org.uk/media/The-Humanitarian-CrisisOf-Rohingya-In-Rakhine-State.pdf.

“The New Light of Myanmar", Burmese News Paper, 21 Feb 2013, http://www.burmalibrary.org/docsMA2013/NLM2013-02-21.pdf, accessed 21 Feb 2013.

Thwe, Francis Khoo, "Myanmar Buddhist Monks Back President Thein Sein's Move to Expel Rohingyas", AsiaNews.it, 4 Sep 2012, http:// www.asianews.it/news-en/Buddhist-monks-back-President-TheinSein $\%$ E2\%80\%99s-move-to-expel-Rohingyas-25723.html, accessed 19 Nov 2015.

Tisnadibrata, Ismira Lutfia, "Khabar: Burma Welcomes Indonesia's Engagement: Natalegawa”, Khabarsoutheastasia.com, 16 Jan 2013, http://khabarsoutheastasia.com/en_GB/articles/apwi/articles/ features/2013/01/16/feature-03, accessed 17 Jan 2013.

Weng, Lawi, "Burmese Muslims cancel Eid Festivities", Irrawaddy.com, 24 Nov 2012, http:/ /www.irrawaddy.com/conflict/burmese-muslimscancel-eid-festivities.html, accessed 24 Oct 2012.

----, "OIC Delegation met by angry protesters in Sittwe", Irrawaddy.com, Al-jāmi'ah, Vol. 53, No. 1, 2015 M/1436 H 
Naw Lily Kadoe \& Fatimah Husein

11 Dec 2013, http://www.irrawaddy.com/burma/oic-delegationmet-angry-protesters-sittwe.html, accessed 15 Nov 2013.

Yegar, Moshe, The Muslims of Burma: A Study of Minority Group, Wiesbaden: Otto Harrassowitz, 1972.

Zaw, Aung, "Rohingya Attacks Stem from Myanmar's Troubled History", The National, 23 Aug 2012, http://www.thenational.ae/ thenationalconversation/comment/rohingya-attacks-stem-frommyanmars-troubled-history, accessed 13 Nov 2015. 